\title{
Isolation and Screening of Silicate Bacteria from Various Habitats for Biological Control of Phytopathogenic Fungi*
}

\author{
Zakira Naureen ${ }^{1,2 \#, ~ M u h a m m a d ~ A q e e l 2, ~ M u h a m m a d ~ N a d e e m ~ H a s s a n ², ~}$ \\ Syed Abdullah Gilani' ${ }^{1}$, Nahla Bouqellah ${ }^{3}$, Fazal Mabood' ${ }^{1}$, Javid Hussain' ${ }^{1}$, Fauzia Y. Hafeez ${ }^{2}$ \\ ${ }^{1}$ Department of Biological Sciences and Chemistry, University of Nizwa, Birkat Al Mawz, Oman \\ ${ }^{2}$ COMSATS University, Chak Shehzad, Islamabad, Pakistan \\ ${ }^{3}$ Department of Biology, Taibah University Madina, Saudi Arabia \\ Email:"zakira@unizwa.edu.om
}

Received 27 March 2015; accepted 12 November 2015; published 16 November 2015

Copyright (C) 2015 by authors and Scientific Research Publishing Inc.

This work is licensed under the Creative Commons Attribution International License (CC BY). http://creativecommons.org/licenses/by/4.0/

(c) (i) Open Access

\begin{abstract}
Silicate solubilizing bacteria (SSB) can play an efficient role in soil by solubilizing insoluble forms of silicates. In addition to this some SSB can also solubilize potassium and phosphates, hence increasing soil fertility and enhancing plant defense mechanisms. A total of 111 bacterial strains were isolated from various habitats of Pakistan and screened for solubilization of silicate, phosphate and potassium on respective media. Out of these, 35 bacterial isolates were capable of solubilizing either silicate, phosphate or potassium. Amongst these 7 bacterial isolates were capable of solubilizing all three minerals tested. The highest silicate (zone diameter $54 \mathrm{~mm}$ ) and phosphate solubilization (zone diameter $55 \mathrm{~mm}$ ) was observed for bacterial isolate NR-2 while the highest potassium solubilization was observed for $\mathrm{NE}-4 \mathrm{~b}$ (zone diameter $11 \mathrm{~mm}$ ). Dual culture antagonistic assays were carried out by using these bacterial isolates against four plant pathogenic fungi Magnaporthae grisae, Rhizoctonia solani, Altarnaria alternata and Macrophomina pheasolina. Mean zone of inhibition of these bacterial isolates against the four pathogenic fungi ranged between $4 \mathrm{~mm}$ to $39 \mathrm{~mm}$. The largest zone of inhibition against all four bacterial strains was recorded for bacterial isolate NR-2 followed by NE-4b. These strains will be further investigated for their plant growth promoting activities in the future.
\end{abstract}

\section{Keywords}

Silicate Solubilizing Bacteria, Biocontrol, Phytopathogenic Fungi

\footnotetext{
*Biocontrol of phytopathogenic fungi by silicate solubilizing bacteria.

"Corresponding author.
}

How to cite this paper: Naureen, Z., Aqeel, M., Hassan, M.N., Gilani, S.A., Bouqellah, N., Mabood, F., Hussain, J. and Hafeez, F.Y. (2015) Isolation and Screening of Silicate Bacteria from Various Habitats for Biological Control of Phytopathogenic Fungi. American Journal of Plant Sciences, 6, 2850-2859. http://dx.doi.org/10.4236/ajps.2015.618282 


\section{Introduction}

Silicon (Si) enhances the growth, development and yield of many plants and is reported to decrease the incidence of many fungal diseases in different pathosystems by strengthening the cell walls and especially the outer membrane of epidermal cells in leaves thus increasing resistance to the penetration of pathogenic fungi [1] [2]. Silicon benefits the plants in several other ways by accelerating growth, conferring rigidity to leaves thus maximizing leaf surface area for photosynthesis and mitigating the effects of abiotic stresses like drought, salt and metal toxicity in several plants including wheat, rice, sugarcane, cucumber, tomato, citrus and barley [3]-[8]. Despite of its abundance in earth's crust it is mostly present in insoluble forms that cannot be readily absorbed by plant roots [9] [10]. It remains in insoluble form unless solubilized by weathering action of rocks or biological activity of plant roots and microorganisms. Silicate solubilizing bacteria (SSB) can play an efficient role here by solubilizing insoluble forms of silicates hence increasing soil fertility and enhancing plant defense mechanisms [9]. The solubilized $\mathrm{Si}$ in the form of orthosilicic acid $\left(\mathrm{H}_{4} \mathrm{SiO}_{4}\right)$ is absorbed along with water [10]. Si is accumulated in the form of silica gel and is deposited in epidermal cells, scelerenchyma, vascular bundles and in florescence brackets in cereals [11]. The accumulated Si not only improves growth and yield of these plants but is also involved in induction of systemic resistance (ISR) against pests and diseases [12].

The present study was carried out to isolate and characterize silicate solubilizing bacteria from various habitats and evaluation of antagonistic activity against four major crop pathogens Magnaporthae grisae, Rhizoctonia solani, Altarnaria alternata and Macrophomina pheasolina.

\section{Material and Methods}

\subsection{Collection of Soil Samples from Different Locations}

Soil samples were collected from various habitats in Pakistan (Table 1). Soil samples were also collected from fields which had been under routine cultivation of rice, wheat and sugarcane (Table 1) as these crops are high silicate accumulators. Half $\mathrm{Kg}$ of each soil sample was collected at a depth of $10 \mathrm{~cm}$ from top soil. The samples were then air dried and ten gram of each air-dried soil sample was transferred to $100 \mathrm{~mL}$ of sterile distilled water in a $250 \mathrm{ml}$ Erlenmeyer flask separately. The samples were than incubated on a rotary shaker $(120 \mathrm{rpm})$ for 30 min at room temperature as described by [13]. Serial dilutions of each soil sample, ranging from $10^{-1}$ to $10^{-5}$ was prepared in sterile water. One $\mathrm{mL}$ aliquot of the appropriate dilution $\left(10^{-5}\right)$ was spread on plates containing Luria Bertani (LB) agar. Plates were incubated at $30^{\circ} \mathrm{C} \pm 1^{\circ} \mathrm{C}$ for $24-48 \mathrm{~h}$ and colonies were examined. Morphologically distinct colonies were counted, selected, purified and maintained in LB broth amended with glycerol [14].

\subsection{Morphological Characterization}

Selected bacterial isolates were purified and plated on LB agar plates. Morphological characteristics were studied for pure single colonies [14].

\subsection{Silicate Solubilization}

Bacterial isolates from different soil samples were then spread on agar plates containing silicate medium with $0.25 \%$ insoluble magnesium trisilicate [15]. Plates were incubated at a temperature of $30^{\circ} \mathrm{C} \pm 1{ }^{\circ} \mathrm{C}$ for $36-72 \mathrm{~h}$. After the incubation period, the bacterial colonies exhibiting clear zones around them were selected for further investigations.

Percentage of silicate solubilizing bacteria was checked for each soil sample and calculated as follows.

$\%$ age silicate solubilizers $=$ Number of silicate solubilizing bacteria/total bacteria $\times 100$

\subsection{Phosphate Solubilization}

All of the isolated bacterial isolates were checked for phosphate solubilization on Pikoviskaya agar plates [16]-[18]. Clear zone diameter was recorded after 24 to $72 \mathrm{~h}$.

$\%$ age Phosphate solubilizers $=$ Number of silicate solubilizing bacteria/total bacteria $\times 100$ 
Table 1. Morphological characterization, Si, P and K solubilization of 35 bacterial isolates from various habitats in Pakistan.

\begin{tabular}{|c|c|c|c|c|c|c|c|c|}
\hline $\begin{array}{l}\text { Serial } \\
\text { No. }\end{array}$ & Strain & $\begin{array}{l}\text { Origin/ } \\
\text { Location }\end{array}$ & $\begin{array}{c}\text { Colony } \\
\text { Morphology }\end{array}$ & $\begin{array}{c}\text { Gram } \\
\text { Reaction }\end{array}$ & $\begin{array}{c}\text { Cell } \\
\text { Morphology }\end{array}$ & $\begin{array}{c}\text { Silicate } \\
\text { Solubilization } \\
\text { Zone }(\mathbf{m m})\end{array}$ & $\begin{array}{l}\text { P-Solubilization } \\
\text { Zone (mm) }\end{array}$ & $\begin{array}{c}\text { K-Solubilization } \\
\text { (mm) }\end{array}$ \\
\hline 1 & NE-1 & $\begin{array}{l}\text { Wheat root } \\
\text { endosphere, } \\
\text { Narowal }\end{array}$ & $\begin{array}{l}\text { White, irregular, } \\
\text { umbonate }\end{array}$ & +ve & Rod & 0 & 0 & 4 \\
\hline 2 & NE-2 & $\begin{array}{c}\text { Wheat root en- } \\
\text { dosphere, Narow- } \\
\text { al }\end{array}$ & $\begin{array}{l}\text { White, } \\
\text { irregular } \\
\text { convex }\end{array}$ & +ve & Long rods & 12 & 25 & 3 \\
\hline 3 & NE-3 & $\begin{array}{l}\text { Wheat root } \\
\text { endosphere, } \\
\text { Narowal }\end{array}$ & $\begin{array}{l}\text { Off white, } \\
\text { circular, raised }\end{array}$ & +ve & Short rods & 6 & 50 & 6 \\
\hline 4 & NE-4 & $\begin{array}{l}\text { Wheat root } \\
\text { endosphere, } \\
\text { Narowal }\end{array}$ & $\begin{array}{c}\text { Fluorescent } \\
\text { yellow, smooth } \\
\text { circular colonies }\end{array}$ & -ve & Long rods & 17 & 24 & 2 \\
\hline 5 & NE-4b & $\begin{array}{l}\text { Wheat root } \\
\text { endosphere, } \\
\text { Narowal }\end{array}$ & $\begin{array}{c}\text { Yellow, } \\
\text { irregular, Lobate, } \\
\text { raised }\end{array}$ & $+\mathrm{ve}$ & Rods & 34 & 28 & 11 \\
\hline 6 & NE-5 & $\begin{array}{l}\text { Wheat root } \\
\text { endosphere, } \\
\text { Narowal }\end{array}$ & $\begin{array}{l}\text { White, smooth } \\
\text { round, entire }\end{array}$ & +ve & $\begin{array}{l}\text { Rods present } \\
\text { in chains }\end{array}$ & 7 & 28 & 5 \\
\hline 7 & NR-2 & $\begin{array}{l}\text { Wheat rhizos- } \\
\text { phere Narowal }\end{array}$ & $\begin{array}{l}\text { White, irregular, } \\
\text { large, flat }\end{array}$ & +ve & $\begin{array}{c}\text { Rods } \\
\text { medium sized }\end{array}$ & 54 & 55 & 7 \\
\hline 8 & NR-3 & $\begin{array}{l}\text { Wheat rhizos- } \\
\text { phere Narowal }\end{array}$ & $\begin{array}{l}\text { Off white, } \\
\text { irregular } \\
\text { medium sized } \\
\text { undulate }\end{array}$ & +ve & Rods & 9 & 12 & 6 \\
\hline 9 & R-1 & $\begin{array}{l}\text { Soil sample } \\
\text { Rawalpindi }\end{array}$ & $\begin{array}{l}\text { White, } \\
\text { circular, } \\
\text { elevated }\end{array}$ & - ve & Cocci & 5 & 0 & 4 \\
\hline 10 & $\mathrm{R}-2$ & $\begin{array}{l}\text { Soil sample } \\
\text { Rawalpindi }\end{array}$ & $\begin{array}{l}\text { Milky, } \\
\text { irregular, flat }\end{array}$ & $+\mathrm{ve}$ & Rods & 0 & 0 & 4 \\
\hline 11 & R-6 & $\begin{array}{l}\text { Soil sample } \\
\text { Rawalpindi }\end{array}$ & $\begin{array}{l}\text { White, } \\
\text { circular, serrate, }\end{array}$ & - ve & Rods & 0 & 0 & 8 \\
\hline 12 & $\mathrm{R}-8$ & $\begin{array}{l}\text { Soil sample } \\
\text { Rawalpindi }\end{array}$ & $\begin{array}{l}\text { White, circular, } \\
\text { raised }\end{array}$ & -ve & Short rods & 0 & 10 & 0 \\
\hline 13 & WE 1 & $\begin{array}{l}\text { Wheat root } \\
\text { Khushab }\end{array}$ & $\begin{array}{l}\text { Opaque, irregular, } \\
\text { convex }\end{array}$ & -ve & Long rods & 0 & 20 & 0 \\
\hline 14 & WE 2 & $\begin{array}{l}\text { Wheat root } \\
\text { Khushab }\end{array}$ & $\begin{array}{c}\text { Creamy, rhizoid, } \\
\text { lobate }\end{array}$ & +ve & Short rods & 0 & 15 & 0 \\
\hline 15 & WE 3 & $\begin{array}{l}\text { Wheat root } \\
\text { Khushab }\end{array}$ & $\begin{array}{c}\text { Circular, centrally } \\
\text { dotted }\end{array}$ & +ve & Cocci & 20 & 25 & 0 \\
\hline 16 & EM 5 & $\begin{array}{l}\text { Endosphere of } \\
\text { mint Morkallan }\end{array}$ & $\begin{array}{l}\text { White, circular, } \\
\text { entire, raised }\end{array}$ & $-\mathrm{ve}$ & Rods & 15 & 10 & 0 \\
\hline 17 & EM 6 & $\begin{array}{l}\text { Endosphere of } \\
\text { mint Morkallan }\end{array}$ & $\begin{array}{l}\text { Pink, circular, } \\
\text { entire }\end{array}$ & +ve & $\begin{array}{l}\text { Filamentous } \\
\text { rods }\end{array}$ & 10 & 7 & 0 \\
\hline 18 & EM 7 & $\begin{array}{l}\text { Endosphere of } \\
\text { mint Morkallan }\end{array}$ & $\begin{array}{c}\text { Off white } \\
\text { circular, entire }\end{array}$ & -ve & Rods & 25 & 18 & 0 \\
\hline
\end{tabular}




\section{Continued}

\begin{tabular}{|c|c|c|c|c|c|c|c|c|}
\hline 19 & RM 1 & $\begin{array}{l}\text { Rhizosphere of } \\
\text { mint Morkallan }\end{array}$ & $\begin{array}{l}\text { Dirty white, } \\
\text { irregular, flat }\end{array}$ & -ve & Short rods & 30 & 22 & 0 \\
\hline 20 & RM 2 & $\begin{array}{l}\text { Rhizosphere of } \\
\text { mint Morkallan }\end{array}$ & $\begin{array}{l}\text { Circular, gummy, } \\
\text { elevated }\end{array}$ & +ve & Short rods & 12 & 21 & 0 \\
\hline 21 & RM 3 & $\begin{array}{l}\text { Rhizosphere of } \\
\text { mint Morkallan }\end{array}$ & $\begin{array}{l}\text { White, irregular, } \\
\text { elevated }\end{array}$ & +ve & $\begin{array}{c}\text { Rods } \\
\text { medium sized }\end{array}$ & 14 & 10 & 0 \\
\hline 22 & RM 4 & $\begin{array}{l}\text { Rhizosphere of } \\
\text { mint Morkallan }\end{array}$ & $\begin{array}{l}\text { White, small } \\
\text { circular, flat }\end{array}$ & -ve & Cocci & 10 & 5 & 0 \\
\hline 23 & AYM-1 & $\begin{array}{l}\text { Soil sample } \\
\text { Ayubia }\end{array}$ & $\begin{array}{l}\text { White, round } \\
\text { smooth }\end{array}$ & Gram - ve & Cocci, chains & 22 & 10 & 0 \\
\hline 24 & AYM-2 & $\begin{array}{l}\text { Soil sample } \\
\text { Ayubia }\end{array}$ & $\begin{array}{l}\text { White, irregular, } \\
\text { smooth, small sized } \\
\text { colonies }\end{array}$ & Gram - ve & Cocci & 12 & 18 & 0 \\
\hline 25 & AYM-3 & $\begin{array}{l}\text { Soil sample } \\
\text { Ayubia }\end{array}$ & $\begin{array}{c}\text { White, round } \\
\text { elevated, medium } \\
\text { sized }\end{array}$ & Gram - ve & $\begin{array}{l}\text { Cocci, bunches, } \\
\text { isolated in the } \\
\text { form of pairs } \\
\text { also. }\end{array}$ & 10 & 24 & 0 \\
\hline 26 & SLB-1 & $\begin{array}{l}\text { Soil sample } \\
\text { Nathia Gali }\end{array}$ & $\begin{array}{c}\text { circular pointed } \\
\text { small white gummy } \\
\text { colonies }\end{array}$ & Gram + ve & $\begin{array}{l}\text { Cocci, } \\
\text { present in the } \\
\text { form of chains }\end{array}$ & 24 & 19 & 0 \\
\hline 27 & SLB-2 & $\begin{array}{l}\text { Soil sample } \\
\text { Nathia Gali }\end{array}$ & $\begin{array}{l}\text { Round small white } \\
\text { gummy colonies }\end{array}$ & Gram - ve & $\begin{array}{l}\text { Cocci, } \\
\text { branched } \\
\text { chains }\end{array}$ & 30 & 22 & 0 \\
\hline 28 & SLB-3 & $\begin{array}{l}\text { Soil sample } \\
\text { Nathia Gali }\end{array}$ & $\begin{array}{c}\text { Round elevated } \\
\text { small white gummy } \\
\text { colonies }\end{array}$ & Gram + ve & $\begin{array}{l}\text { Cocci, in the } \\
\text { form of pair } \\
\text { and also present } \\
\text { in the form of } \\
\text { bunches }\end{array}$ & 8 & 5 & 0 \\
\hline 29 & SLB-4 & $\begin{array}{l}\text { Soil sample } \\
\text { Nathia Gali }\end{array}$ & $\begin{array}{l}\text { Small white gummy } \\
\text { colonies }\end{array}$ & Gram - ve & Short rods & 17 & 21 & 0 \\
\hline 30 & SLB-5 & $\begin{array}{l}\text { Soil sample } \\
\text { Nathia Gali }\end{array}$ & $\begin{array}{l}\text { Dot size small white } \\
\text { gummy colonies }\end{array}$ & Gram - ve & $\begin{array}{l}\text { Cocci, } \\
\text { present in the } \\
\text { form of pairs, } \\
\text { chains, } \\
\text { bunches. }\end{array}$ & 13 & 20 & 0 \\
\hline 31 & SLB-6 & $\begin{array}{l}\text { Soil sample } \\
\text { Nathia Gali }\end{array}$ & $\begin{array}{l}\text { Round pointed } \\
\text { small white gummy } \\
\text { colonies }\end{array}$ & Gram - ve & $\begin{array}{l}\text { Cocci, bunches, } \\
\text { pair and } \\
\text { isolated } \\
\text { forms. }\end{array}$ & 14 & 22 & 0 \\
\hline 32 & SLB-7 & $\begin{array}{l}\text { Soil sample } \\
\text { Nathia Gali }\end{array}$ & $\begin{array}{l}\text { Round pointed } \\
\text { small off white } \\
\text { gummy colonies }\end{array}$ & Gram + ve & $\begin{array}{l}\text { Cocci, } \\
\text { randomly } \\
\text { present. }\end{array}$ & 10 & 13 & 0 \\
\hline 33 & SLB-8 & $\begin{array}{l}\text { Soil sample } \\
\text { Nathia Gali }\end{array}$ & $\begin{array}{l}\text { Round pointed } \\
\text { small white gummy } \\
\text { colonies }\end{array}$ & Gram + ve & $\begin{array}{l}\text { Cocci in the } \\
\text { form of groups. }\end{array}$ & 10 & 0 & 6 \\
\hline 34 & PTN 8 & $\begin{array}{l}\text { Potato field } \\
\text { Nathya Gali }\end{array}$ & $\begin{array}{l}\text { White, irregular } \\
\text { elevated }\end{array}$ & Gram - ve & Cocci, chains & 8 & 17 & 0 \\
\hline 35 & PTN 24 & $\begin{array}{l}\text { Potato field } \\
\text { Nathya Gali }\end{array}$ & $\begin{array}{l}\text { White, circular, } \\
\text { entire, elevated }\end{array}$ & Gram - ve & Rods & 6 & 0 & 0 \\
\hline
\end{tabular}




\subsection{Potash Solubilization}

Bacterial isolates were checked for potassium solubilization on plates containing Alexandrov's medium containing sucrose (5 g), $\mathrm{Na}_{2} \mathrm{PO}_{4}(2 \mathrm{~g}), \mathrm{MgSO}_{4} \cdot 7 \mathrm{H}_{2} \mathrm{O}(0.5 \mathrm{~g}), \mathrm{FeCl}_{3}(0.005 \mathrm{~g}), \mathrm{CaCO}_{3}(0.1 \mathrm{~g})$, glass beads (1 g) in 1 $\mathrm{L}$ of deionized distilled water at a pH of 7.4 [19]. Clear zone formation around the bacterial growth was observed after 48 - $72 \mathrm{~h}$.

$\%$ age Potash solubilizers $=$ Number of potash solubilizing bacteria/total bacteria $\times 100$

\subsection{Semi Quantitative Screening of the Bacterial Isolates}

All of the selected bacterial isolates were subjected to semi quantitative mineral ( $\mathrm{Si}$, P and K) solubilization assay in in-vitro conditions. Each bacterial isolates was inoculated on three different bacterial agar media as above and after the incubation period (36 - $72 \mathrm{~h}$ ) at a temperature of $30^{\circ} \mathrm{C} \pm 1^{\circ} \mathrm{C}$, the area of clearing zones was calculated and recorded in mm. Each experiment considering a single bacterial isolate was repeated at least three times.

\subsection{Acid Production by Bacterial Isolates}

Freshly prepared broth cultures of selected bacterial isolates were spread on LB agar plates amended with bromophenol blue and incubated for $24-72 \mathrm{~h}$ at a temperature of $30^{\circ} \mathrm{C} \pm 1{ }^{\circ} \mathrm{C}$. Acid production was detected as blue media turned yellow around bacterial colonies.

\subsection{Antagonistic Assays}

Antagonistic activity of selected bacterial isolates was checked against selected pathogenic fungi including Magnaporthae grisae, Rhizoctonia solani, Altarnaria alternata and Macrophomina pheasolina using dual culture assays as described by Naureen et al. (2009) and Hassan et al. (2010) [14] [18]. Briefly, a 10 mm disc of an actively growing pure culture of pathogenic fungi grown on potato dextrose agar (PDA) was placed at the centre of a Petri dish containing appropriate test medium (rice flour agar RFA; PDA; Tomato juice agar etc.). A circular inoculum of selected bacterial isolates was made with a $6 \mathrm{~cm}$ diameter Petri dish dipped in a suspension of bacterial broth culture $\left(5 \times 10^{9}\right.$-cfu $\left.\cdot \mathrm{mL}^{-1}\right)$ and placed around the fungal disc. Plates were incubated for one week at $30^{\circ} \mathrm{C} \pm 1{ }^{\circ} \mathrm{C}$ and mean zone of inhibition was recorded after 7 days.

Each experiment considering a single bacterial isolate was repeated at least three times.

\subsection{Statistical Analysis}

Each experiment was run thrice and means were calculated.

\section{Results}

Soil samples were collected during April to June 2011 from different habitats in Pakistan including Narowal, Khushab, Kallar Kahar, Chakwal, Bochaal, Miyani, Rawalpindi, Murree, Jhika Gali, Nathia Gali, Ayubia, Barian and Morkallan (Mansehra). Samples were collected either from fields that had been long under cultivation of rice, wheat or sugar cane or from mountainous regions which are rich in minerals. A total of 111 bacterial isolates were isolated from these soil samples and maintained as pure cultures.

Each bacterial strain was checked for silicate, phosphate and potash solubilization on respective medium. Out of 111 bacterial isolates 35 bacterial isolates that showed solubilization of any of the three minerals were selected for further studies. Twenty-nine bacterial isolates were capable of solubilizing magnesium trisilicate, 28 were capable of solubilizing phosphates and 12 were observed to solubilize potash (Table 1). Amongst these 7 bacterial isolates were capable of solubilizing all three minerals tested. The highest silicate (zone diameter 54mm) and phosphate solubilization (zone diameter $55 \mathrm{~mm}$ ) were observed for bacterial isolate NR-2 while highest potassium solubilization was observed for NE-4b (zone diameter $11 \mathrm{~mm}$ ). The highest percentage of silicate solubilizing bacteria was observed in soil samples collected from Ayubia and Nathia Gali mountains where 100\% bacterial isolates were silicate solubilizers while $64 \%$ of the total bacterial population was silicate solubilizers in soil samples obtained from Narowal fields which had been under routine cultivation of wheat and rice (Figure 1). 


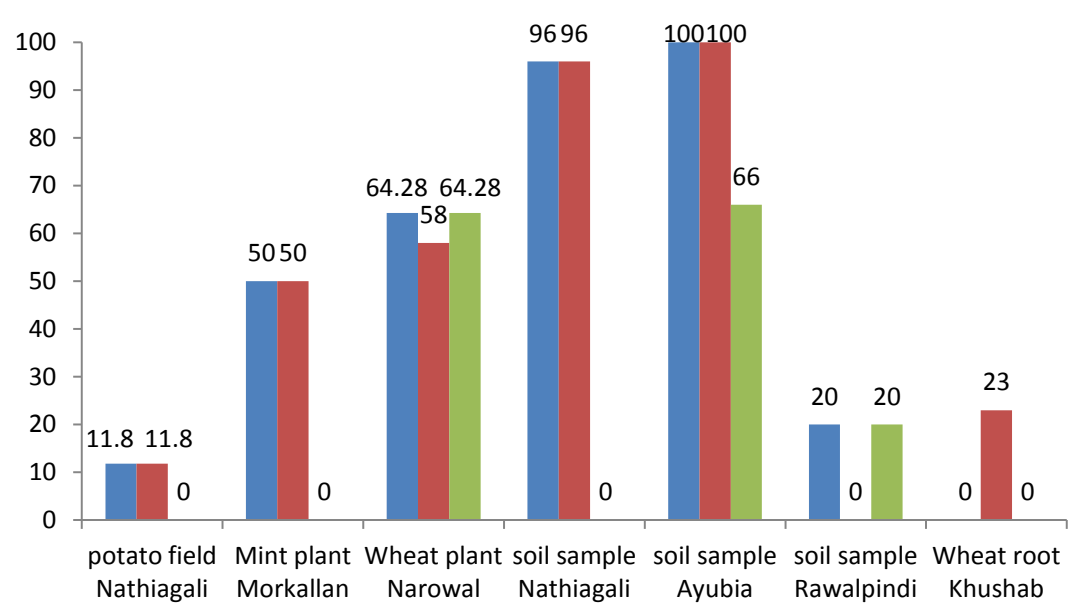

Figure 1. Percentage of silicate, phosphate and potash solubilizing bacteria in plant root and soil samples collected from different area of Pakistan.

A few silicate solubilizers were seen in samples from potato field (Nathia Gali) and wild Mint plant rhizosphere and endosphere which were taken from Morkallan village near Mansehra (Figure 2, Figure 3).

Similarly the highest percentage of phosphate solubilizing bacteria was seen in soil samples from Ayubia and Nathia Gali Mountains and almost all of the silicate solubilizers in these samples were phosphate solubilizers (Figure 3). The highest population of potash solubilizers was seen in soil samples taken from Ayubia Mountains followed by wheat rhizosphere samples taken from Narowal and a few potash solubilizers were seen in soil samples taken from Rawalpindi.

The selected 35 bacterial isolates were checked for antagonistic activity against plant pathogenic fungi such as Magnaporthae grisae, Rhizoctonia solani, Altarnaria alternata and Macrophomina pheasolina and zone of inhibition recorded (Table 2). Almost all of the selected isolates exhibited at least some antagonistic activities against the four pathogens. Mean zone of inhibition of these bacterial isolates against the four pathogenic fungi ranged between $4 \mathrm{~mm}$ to $39 \mathrm{~mm}$. Highest antagonistic activity was observed in case of bacterial strain NR-2, isolated from wheat rhizosphere, against all fungal pathogen followed by NE-4b, isolated from wheat root from Narowal region.

\section{Discussion}

Bacterial isolates can solubilize insoluble minerals such as silicates, phosphates and potash into soluble form by production of organic acids such as 2 keto-gluconic acid, alkalis and polysaccharides [20]. Bacteria have been reported to accelerate the dissolution of silicates by producing excess proton, organic ligands, hydroxyl anion, extra cellular polysaccharides (EPS) and enzymes [21]-[24]. Despite abundance of microorganisms in soil only a few are capable of solubilizing silicates and our results indicated that out of a total of 111 bacterial isolates only 29 were capable of solubilizing silicates. Similarly, phosphate solubilization by bacterial isolates is also attributed to production of gluconic acid, 2 keto-gluconic acid and phosphatases. Our results indicated that almost all of the bacterial isolates capable of solubilizing phosphates and silicates produced acid as detected by yellow halo formation on media containing bromophenol blue and low $\mathrm{pH}$ in broth cultures.

Efficient silicate solubilizing bacteria can help release other essential nutrients in soil [25]. This can be directly due to solubilization of other minerals by silicate solubilizing bacteria or indirectly due to solubilized silicon. We also observed that most of the silicate solubilizers were able to solubilize phosphates with a few exceptions such as bacterial strain NE-1, R1, R2 and AYM-1 which solubilized silicates but not phosphates. It has been previous reported that the solubilized Si improves availability of phosphorus to plants by competing with P fixation sites in soil [25]. Thus Si acts as a substitute for P in plant system. Silicon is reported to increase the availability of Phosphorus indirectly by decreasing the availability of Fe and Mn in plants [26].

Potassium is also one of the major micronutrients required by the plant for optimum growth and yield. Potassium plays a regulatory role in plant being a constituent in 60 different enzymes in plants involved in drought tolerance and water use efficiency. Recent studies have shown that besides drought tolerance potassium plays an 


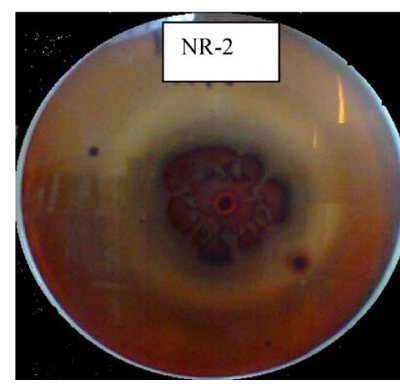

(a)

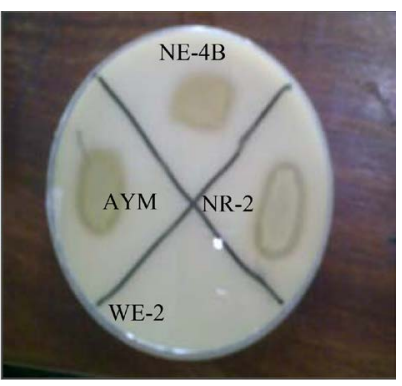

(b)

Figure 2. (a) Acid production by silicate solubilizing bacterial isolate NR-2 (b) Solubilization of silicate on media amended with $0.25 \%$ Magnesium trisilcate.

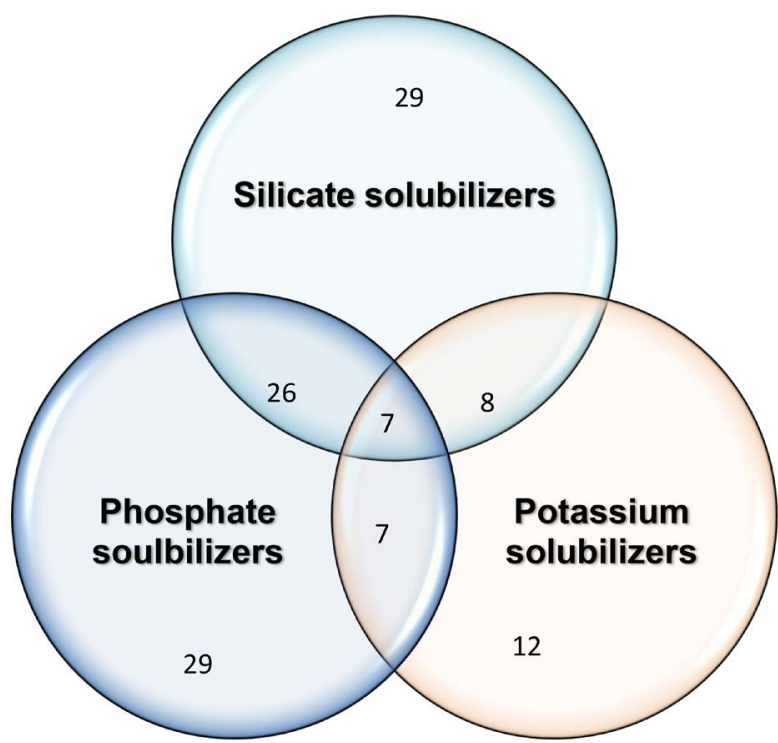

Figure 3. Venn diagram illustrating solubilization of Si, P and K by 35 selected bacterial isolates Values represent actual numbers of bacterial isolates.

important role in various metabolic processes and disease resistance in plants, almost all crops require potassium for optimum growth [27]. Deficiency of potassium leads to symptoms like chlorosis and leaf fall, unhealthy root system and then reduction in nutrient uptake and reduced cytokinin production in roots. This deficiency of potassium in soil can be successfully managed by application of microbial fertilizers based on bacterial isolates that can solubilize potassium in soil. Potassium is mostly present in soil in the form of silicates hence silicate solubilizing bacteria can play an efficient role here by liberating soluble potassium in soil. Our results indicated that some of silicate and phosphate solubilizing bacterial isolates were capable of solubilizing potassium as well while a few, such as R1 and R2, were found to solubilize silicates and potassium but not phosphate as detected by plate assays (Table 1, Figure 3).

In addition to increasing the availability of $\mathrm{Si}, \mathrm{P}$ and $\mathrm{K}$ in soil, the silicate solubilizing bacteria provide a very efficient system of biological control of plant pathogenic fungi. These bacteria can not only directly combat phyto-pathogenic fungi but indirectly by release of $\mathrm{Si}$ in soil which in turn induces disease resistance in plants either by acting as a physical barrier or by acting as a modulator of host resistance to pathogen. Si is deposited beneath the cuticle to form a cuticle-Si double layer which mechanically impedes penetration of fungi and thus disrupts the infection process [26]-[30].

Almost all of the selected bacterial isolates showed at least some antagonistic activities against the four fungal pathogens used. Highest antagonistic activity was observed in case of bacterial isolate NR-2 as shown by maximum zone of inhibition observed against all of the fungal pathogens tested followed by bacterial isolate NE-4b and R-6 respectively. There are several ways by which these silicate solubilizing bacteria can antagonize fungal 
Table 2. Inhibition of phytopathogenic fungi by selected Si, P and K solubilizing bacterial isolates.

\begin{tabular}{|c|c|c|c|c|}
\hline \multirow{2}{*}{ Bacterial Isolates } & \multicolumn{4}{|c|}{ Mean Zone of Inhibition after 7 Days (mm) } \\
\hline & Magnaporthae grisae & Rhizoctonia solani & Altarnaria alternata & Fusarium moniliformae \\
\hline NE-1 & 12 & 11 & 4 & 8 \\
\hline NE-2 & 18 & 18 & 14 & 17 \\
\hline NE-3 & 13 & 7 & 8 & 12 \\
\hline NE-4 & 20 & 18 & 16 & 17 \\
\hline NE-4b & 34 & 29 & 23 & 21 \\
\hline NE-5 & 4 & 6 & 7 & 4 \\
\hline NR-2 & 39 & 33 & 25 & 31 \\
\hline NR-3 & 7 & 8 & 12 & 8 \\
\hline $\mathrm{R}-2$ & 18 & 16 & 17 & 17 \\
\hline $\mathrm{R}-6$ & 29 & 18 & 19 & 13 \\
\hline $\mathrm{R}-8$ & 18 & 21 & 17 & 14 \\
\hline WE 1 & 17 & 11 & 9 & 10 \\
\hline WE 2 & 13 & 12 & 11 & 8 \\
\hline WE 3 & 14 & 14 & 8 & 15 \\
\hline EM 5 & 10 & 7 & 17 & 13 \\
\hline EM 6 & 16 & 5 & 9 & 10 \\
\hline EM 7 & 12 & 11 & 4 & 8 \\
\hline RM 1 & 18 & 18 & 14 & 10 \\
\hline RM 2 & 13 & 17 & 27 & 12 \\
\hline RM 3 & 20 & 18 & 16 & 17 \\
\hline RM 4 & 12 & 15 & 14 & 18 \\
\hline AYM-1 & 18 & 18 & 14 & 17 \\
\hline AYM-2 & 13 & 27 & 28 & 12 \\
\hline AYM-3 & 20 & 18 & 16 & 17 \\
\hline SLB-1 & 11 & 11 & 4 & 8 \\
\hline SLB-2 & 18 & 18 & 14 & 17 \\
\hline SLB-3 & 13 & 7 & 8 & 12 \\
\hline SLB-4 & 20 & 18 & 16 & 17 \\
\hline SLB-5 & 12 & 11 & 4 & 8 \\
\hline SLB-6 & 13 & 12 & 11 & 8 \\
\hline SLB-7 & 14 & 14 & 8 & 15 \\
\hline SLB-8 & 10 & 7 & 17 & 13 \\
\hline $\mathrm{R} 1$ & 13 & 12 & 11 & 8 \\
\hline PTN 8 & 14 & 14 & 8 & 15 \\
\hline PTN 24 & 10 & 7 & 17 & 13 \\
\hline
\end{tabular}


pathogens. These include production of hydrolytic enzymes, siderophores, HCN and antibiotics [13] [14] [18]. The antagonistic potential of these bacteria is an important ability of practical utility in development of biopesticides against the fungal pathogens.

These bacterial isolates will be further investigated for combating plant pathogens in green house experiment for a possible development of bioformulations for commercial purpose.

\section{Acknowledgements}

We are grateful to the Pakistan Higher Education Commission for funding this project.

\section{References}

[1] Francois, F., Wilfried, R.B., James, G.M. and Richard, R.B. (2005) Silicon and Plant Disease Resistance against Pathogenic Fungi. FEMS Microbiology Letters, 249, 1-6. http://dx.doi.org/10.1016/j.femsle.2005.06.034

[2] Carver, T.L.W., Zeyen, R.J. and Ahlstrand, G.G. (1987) The Relationship between Insoluble Silicon and Success or Failure of Attempted Primary Penetration by Powdery Mildew (Erysiphe graminis) Germlings on Barley. Physiological and Molecular Plant Pathology, 31, 133-148. http://dx.doi.org/10.1016/0885-5765(87)90012-9

[3] Adatia, M.H. and Besford, R.T. (1986) The Effects of Silicon on Cucumber Plants Grown in Recirculating Nutrient Solution. Annals of Botany, 58, 343-351.

[4] Raid, R.N., Annderson, D.L. and Ulloa, M.F. (1991) Influence of Cultivar and Soil Amendment with Calcium Silicate Slag on Foliar Disease Development and Yield of Sugarcane. Florida Agricultural Experimental Station Journal, Ser. N R-01689.

[5] Winslow, M.D. (1992) Silicon, Disease Resistance, and Yield of Rice Genotypes under Upland Cultural Conditions. Crop Science, 32(5), 1208-1213. http://dx.doi.org/10.2135/cropsci1992.0011183X003200050030x

[6] Datnoff, L.E., Snyder, G.H. and Deran, C.W. (1992) Influence of Silicon Fertilizer Grade on Blast and Brown Spot Development in Rice Yields. Plant Disease, 76, 1182-1184. http://dx.doi.org/10.1094/PD-76-1182

[7] Bélanger, R.R., Benhamou, N. and Menzies, J.G. (2003) Cytological Evidence of an Active Role of Silicon in Wheat Resistance to Powdery Mildew (Blumeria graminis f. sp. tritici). Phytopathology, 93, 402-412. http://dx.doi.org/10.1094/PHYTO.2003.93.4.402

[8] Ma, J.F. and Yamaji, N. (2006) Silicon Uptake and Accumulation in Lower Plants. Trends in Plant Science, 11, 392397. http://dx.doi.org/10.1016/j.tplants.2006.06.007

[9] Vasanthi, N., Saleena, L.M. and Raj, S.A. (2012) Silicon in Day Today Life. World Applied Sciences Journal, 17, 1425-1440.

[10] Rodrignes, F.A. and Datnoff, L.E. (2005) Silicon and Rice Disease Management. Fitopatologia Brasileira, 30, 457469. http://dx.doi.org/10.1590/S0100-41582005000500001

[11] Lanning, F.C., Ponnaiya, B.W.X. and Crumpton, C.F. (1958) The Chemical Nature of Silica in Plants. Plant Physiology, 33, 339-343. http://dx.doi.org/10.1104/pp.33.5.339

[12] Vijayapriya, M. and Muthukkaruppan, S.M. (2010) Isolation and Screening of Silicate Solubilizing Bacteria and Its Biocontrol Nature against Pyricularia oryzae. International Journal of Recent Scientific Research, 4, 87-91.

[13] Naureen, Z., Hafeez, F.Y., Hussain, J., Al Harrasi, A., Bouqellah, N. and Roberts, M.R. (2015) Suppression of Incidence of Rhizoctonia solani in Rice by Siderophore Producing Rhizobacterial Strains Based on Competition for Iron. European Scientific Journal, 11, 186-207.

[14] Naureen, Z., Price, A.H., Wilson, M.J., Hafeez, F.Y. and Roberts, M.R. (2009) Suppression of Rice Blast Disease by Siderophore-Producing Bioantagonistic Bacterial Isolates Isolated from the Rhizosphere of Rice Grown in Pakistan. Crop Protection, 28, 1052-1060. http://dx.doi.org/10.1016/j.cropro.2009.08.007

[15] Bunt, J.S. and Rovira, A.D. (1955) Microbiological Studies of Some Sub Antarctic Soils. Journal of Soil Science, 6, 119-128. http://dx.doi.org/10.1111/j.1365-2389.1955.tb00836.X

[16] Yasmin, S., Baker, M.A.R., Malik, K.A. and Haffez, F.Y. (2004) Isolation, Characterization and Beneficial Effects of Rice-Associated Plant Growth-Promoting Bacteria from Zanzibar Soils. Journal of Basic Microbiology, 44, $241-252$. http://dx.doi.org/10.1002/jobm.200310344

[17] Naureen, Z., Hameed, S., Yasmin, S., Malik, K.A. and Hafeez, F.Y. (2005) Characterisation and Screening of Bacteria from Maize Grown in Indonesian and Pakistani Soils. Journal of Basic Microbiology, 45, 447-459. http://dx.doi.org/10.1002/jobm.200510566

[18] Hassan, M.N., Afghan, S. and Hafeez, F.Y. (2010) Suppression of Red Rot Caused by Colletotrichum falcatum on Su- 
garcane Plants Using Plant Growth-Promoting Rhizobacteria. BioControl, 55, 531-542. http://dx.doi.org/10.1007/s10526-010-9268-z

[19] Lü, C. and Huang, B. (2010) Isolation and Characterization of Azotobacteria from Pine Rhizosphere. African Journal of Microbiology Research, 4, 1299-1306.

[20] Joseph, M.H., Dhargave, T.S., Deshpande, C.P. and Srivastava, A.K. (2015) Microbial Solubilisation of Phosphate: Pseudomonas versus Trichoderma. Annals of Plant and Soil Research, 17, $227-232$.

[21] Berthelin, J. and Belgy, G. (1979) Microbial Degradation of Phyllosilicates during Simulated Podzolization. Geoderma, 21, 297-310. http://dx.doi.org/10.1016/0016-7061(79)90004-1

[22] Malinovskaya, I.M., Kosenko, L.V., Votselko, S.K. and Podgorskii, V.S. (1990) Role of Bacillus Mucilaginosus Polysaccharide in Degradation of Silicate Minerals. Mikrobiologiya, 59, 49-55.

[23] Hiebert, F.K. and Bennett, P.C. (1992) Microbial Control of Silicate Weathering in Organic-Rich Ground Water. Science, 258, 278-281. http://dx.doi.org/10.1126/science.258.5080.278

[24] Barker, W.W., Welch, S.A., Chu, S. and Baneld, J.F. (1998) Experimental Observations of the Effects of Bacteria on Aluminosilicate Weathering. American Mineralogist, 83, 1551-1563.

[25] Muralikannan, N. and Anthomiraj, S. (1998) Occurrence of Silicate Solublising Bacteria in Rice Ecosystem. The Madras Agricultural Journal, 85, 47-50.

[26] Sahebi, M., Hanafi, M., Siti, A., Akmar, N., Rafii, M.Y., Azizi, P., Tengoua, F.F., Azwa, J.N.M. and Shabanimofrad, M. (2015) Importance of Silicon and Mechanisms of Biosilica Formation in Plants. Biomed Research International, 2015, Article ID: 396010. http://dx.doi.org/10.1155/2015/396010

[27] Simonsson, M., Andersson, S., Andrist-Rangel, Y., Hillier, S., Mattsson, L. and Oborn, I. (2007) Potassium Release and Fixation as a Function of Fertilizer Application Rate and Soil Parent Material. Geoderma, 140, 188-198. http://dx.doi.org/10.1016/j.geoderma.2007.04.002

[28] Chinnasami, K.N. and Chandrasekaran, S. (1978) Silica Status in Certain Soils of Tamil Nadu. The Madras Agricultural Journal, 65, 743-746.

[29] Sugumaran, P. and Janarthanam, B. (2007) Solubilization of Potassium Containing Minerals by Bacteria and Their Effect on Plant Growth. World Journal of Agricultural Sciences, 3, 350-355.

[30] Bowen, P., Menzies, J. and Ehret, D. (1992) Soluble Silicon Sprays Inhibit Powdery Mildew Development on Grape Leaves. Journal of the American Society for Horticultural Science, 117, 906-912. 